\title{
NEW BORDERS AND NEW SPACES: THE CASE OF THE ASYLUM SEEKER IN STRASBOURG, FRANCE
}

\author{
PATRICIA ZANDER \\ Strasbourg University, Complex Geographic Systems Laboratory, Faculty of Geography and Development, \\ Strasbourg, France
}

Manuscript received July 9, 2010

Revised version November 16, 2010

\begin{abstract}
ZANDER P., New borders and new spaces: The case of the asylum seeker in Strasbourg, France. Quaestiones Geographicae 29(4), Bogucki Wydawnictwo Naukowe, Poznań 2010, pp. 53-63, 1 fig., 3 tables. DOI 10.2478/v10117010-0031-4, ISBN 978-83-62662-30-2, ISSN 0137-477X.
\end{abstract}

ABSTRACT: The need for borders seems an old-fashioned notion, especially when we consider the border in its most basic sense: as a barrier and a filter. Within the European Union, the idea of the disappearing border is underlined when we see its physical signs such as buildings and checkpoints fall out of use or disappear. We submit here that due to the complex interplay between supra-national, national and local structures today, the notion of the border has instead evolved and become less visible, but very present, and very complex.

When we examine the particular case of the asylum seeker in Strasbourg, France, we see that even in this 'borderless' city administrative mechanisms keep him 'out', even when he is physically in our midst, by creating 'non-spaces', or by manipulating his use of time and everyday spaces so that he cannot anchor himself.

KEY WORDS: borders, asylum, everyday spaces, Strasbourg

Patricia Zander, Université de Strasbourg, Faculté de Géographie et d'Aménagement, Laboratoire 'Systèmes géographiques complexes', 3 rue de l'Argonne, 67083 Strasbourg Cedex, France; e-mail: patricia.zander@unistra.fr

European borders are being constructed beneath our very eyes. Their role in space, their governance and representation are evolving rapidly as a function of a number of factors: changing social demands and practices, an evolving political climate, and complex relationships between political powers and political partners.

We propose here to bring to light a new type of border which is being constructed in the heart of European cities. This border is born out of a need for the State to control its external borders, whereas its territory has been changed dramatically by new spatial practices (numerous entering and exiting flows) and new political powers (the development of the European Union as a po- litical power). This border is a result of complex political governance which links, in particular, political, administrative and legal powers, and associations. The former interior frontiers seem to have disappeared.

If we consider the city of Strasbourg, France, where historically the frontier between France and Germany has been vitally important, the border seems to have all but disappeared today. The border offices and checkpoints are closed. We barely notice when we move from one country to the other.

In fact, the national border, far from having disappeared, has instead profoundly changed in an era of networks and a multiplication of supra- 
national structures. The border endures and is complex. In order to demonstrate that this is indeed the case, we have chosen to look at it from the point of view of the asylum seeker.

Initially, this may seem to be a simplistic approach as the asylum seeker may be seen as experiencing the border in its most classic sense the border as a barrier and a filter, and as such it can be seen as a simple tool that the State uses for managing migratory flows. However, let us see how complex this "simple" notion of barrier and filter has become today.

Asylum seeking represents a physical space and networks of different kinds. Asylum seekers are constantly coming and going and using social networks in their often never-ending quest for territory. Examining the case of the asylum seeker in his everyday space allows us to consider a further evolution of the border today: one where we keep the asylum seeker "outside" by constantly disrupting his links with everyday space.

Using the case of the asylum seeker is an interesting approach for another reason. The issues of asylum provoke, among the diverse group of interested parties (institutional, political, local associations), a debate about fundamental values that are regularly in conflict: democracy, the host place, and social justice, for example.

We start by considering the border in the classical sense as experienced by the asylum seeker in France. After an initial look at the legal and administrative definitions of the border and of the path of an asylum seeker and the types of border spaces that have been constructed in the particular situation of asylum seekers, we enrich the analysis using the city of Strasbourg as a case study. We focus on the translation of the border into the everyday spaces of the asylum seeker and consider how the definition of the border may have evolved from a simplistic national barrier or filter to a more complex, individual and personal boundary. We conclude by posing more complex questions that this evolution raises.

\section{The evolving right to seek asylum in France: a need for new borders and (non-) spaces}

The question of asylum has evolved considerably over the last 50 years, in dialogue and in fact. Since the Second World War, the mobility of populations has never ceased to grow, created by the development of Western economic and political models. The number of refugees grew from 2.3 million in the 1980s to 6.1 million in the 1990s. It was predicted to reach 6.1 million by 2006 , to which we have to add 25 million displaced people (UNHCR 2001).

Historically, asylum has been, above all, a question of "humane" rights, and of being granted a safe space: religious initially, then these spaces were appropriated by growing political powers, such as French royalty under the rule of François the First. With an increase in the number of massive population movements, we have seen a growing international recognition of the status of a refugee (Geneva Convention 1951, 1967 protocol, ratified by France in 1971). This is the "conventional" right to asylum; it also gives a status to people who are persecuted for reasons such as race, religion, opinion. France, which recognised the "conventional" right, albeit with certain provisos, also has a "constitutional" asylum (written into the Constitution in 1946) which concerns people "who are persecuted for their actions in favour of liberty" as well as "subsidiary protection" for people who are exposed to inhuman or degrading treatment.

Strangely though, despite the growing number of asylum seekers and the growing recognition of their rights, we have seen a sharp drop in the number of asylum seekers recorded since 2001. In 2005, the EU recorded a drop of $46 \%$ from the 2001 figure (Refugee Forum 2006). Why this paradox?

On looking more closely, we note that today, more than a question of human rights, the right to asylum is a question of economics, and above all, of internal politics between the Member States and the European Union. This, in turn, creates a complex and unclear set of borders and spaces for the asylum seeker. 


\subsection{Tug of war: the EU versus its Member States}

The "Common European System of Asylum" is a major reform the basis of which goes back to the constitution of the Common Market. From 1985 to 1999, the Member States and the European Union (EU) arm-wrestled each other into a first Community policy on migration (which, from a legal point of view, did not mean "common"). The Treaties of Maastricht and Amsterdam (1991 and 1999) and the Programme of the Hague (2005) make up the major milestones of the process, with four main directives and one European law (cf. the bibliography). These directives, like the directive 2005/85/CE regarding the withdrawal of refugee status, put in place the minimum norms that had to be respected. Such directives have more or less obliged France to revise a certain number of procedures, for fear of being taken to the European Court of Human Rights.

Asylum is therefore part of the legal competencies of the European States and the European Union (Amsterdam 1999): the EU is able to produce texts that are legally binding. This does not signal the end of the prerogatives of the Member States, however. The interpretation of European regulatory frameworks, the handling of individual files of the migrants, the evaluation of the political situation in the migrant's country of origin, still vary from country to country. This has seriously compromised the "communitisation" of migration policy. The legal framework permits the Member States to translate the policy into national laws that allow them to establish their authority on their own territory - interior as well as exterior, such as a toughening of conditions of access to the country. Local interpretation has permitted in France, for example, the law of 10 December 2003 and the decree of 14 August 2004, which forbid French citizens to host people in an "irregular" situation (article L-622-1 of the Code of entry and stay of foreigners and right to asylum - CESEDA).

As a consequence, the right to asylum has become a very complex and ambiguous right. The European law has allowed the States to reinforce their prerogatives; yet, on the other hand, the European Union has also gained the ability to de- cide autonomously and to counter some of the decisions of these same States.

In France, to make things more complex, the right to asylum mixes an administrative right with a legal right, creating a veritable legal "Bermuda Triangle" (Eolas, Diary of a Lawyer, 2005). This makes the border as applied to the asylum seeker one that is managed with doubt and uncertainty. By using a few key texts (European directives and rulings, laws in France) and by reconstructing the "geo-administrative" path of the asylum seeker, it is possible to better understand the nature of this border in France and the spaces created by a right that is undergoing an enormous redefinition.

\subsection{The long road that leads to ... nowhere?}

Since 2006, the French immigration policy framework has become clearly repressive: priority is given to economically "useful" immigration, relegating everyone else who asks for protection to the ranks of "useless" immigration. Consequently, the border for asylum seeking has become tighter, but also less visible, because it now operates initially, and very effectively, at a distance.

The first way in which an asylum seeker confronts the French border has two of the classic properties of a border:

- maintenance at a distance - a long-distance barrier for potential asylum seekers; and

- filtering of asylum seekers at either the external borders of the European Union or at the main border points if the asylum seeker has succeeded, despite everything, and has managed to enter the European territory and get to France.

Maintaining the asylum seeker at a distance manifests itself in new and different ways:

- a restrictive policy for visas that are issued by the consulates;

- coordination of the "management" of the external borders of the European Union (FRONTEX) as well as a surveillance system at the borders (EUROSUR), which is being tried out on the EU extreme southern border;

- the existence of spaces where asylum seekers, contrary to what they declare, are not seen to 
be in danger. This is the idea of "internal asylum", which is interpreted today as part of the territory of origin considered as "safe"; this is also the notion of a "safe country of origin" of which France publishes a regularly updated official list, the only country in Europe to do so. Any asylum seeker coming from this type of space or country cannot submit an application;

- the existence of informal camps in the countries at the outside extremes of the European Union which host transit populations (clearly indicated on the updated map of the site Migreurop, http://www.migreurop.org/IMG/ pdf/carte-fr07.pdf).

These initiatives have given rise to the expression "European fortress" with its outposts of distant camps and detached forts, charged with the task of stopping "the progression" of migrants, including asylum seekers.

The filtering of the candidates for asylum seekers when they have succeeded in reaching France is the second property of the asylum border that also has specific spaces.

To obtain refugee status in France, an asylum seeker has to submit a file along with a justification to the French Office for the Protection of Refugees and the Stateless (Office Français pour la Protection des Réfugiés et Apatrides, or OFPRA) which grants a "yes" or "no" for this status. The path to this OFPRA application is an elaborate, complex, and even confusing process, as we shall see below.

There are two types of entry possible in France: via controlled border points (aeroplane, boat or train) or by other means which are impossible to control systematically. If the asylum candidate has passed through a controlled border point, they enter into a procedure called "border asylum" which examines their request up front and verifies that it is not "manifestly" unjustified (article L221-1 of the Code of entry and stay of foreigners and asylum seekers). If the request is deemed to be justified, the asylum seeker has a number of days to get a file from the Prefecture of the region and to deposit it at OFPRA.

If the asylum candidate arrives in France without being checked, they have to go to a Prefecture (in any region in the territory) in order to obtain an asylum seeker's request form and can deposit it at
OFPRA. Their case is also briefly examined before a file for OFPRA is delivered. As a consequence, the Prefecture of the region is the essential border point which either grants access to OFPRA to these asylum seekers, or not. In effect, the Prefecture has a number of discretionary powers: verifying the conformity of the application; granting a permission to stay (titre de sejour) without any justification, as long as the case is in line with European directives; and managing the creation, extension and closing of specific places that are dedicated to the asylum seekers, the Centres of Administrative Retention (CRA) and the Host Centres for Asylum Seekers, CADA (1,824 places in 1992, 17,470 places in 2005: Refugee Forum, 2006).

A third phase waits for the asylum seeker depending on the decision made by OFPRA. If the request is accepted, a very variable "titre de sejour" is granted (renewable from a few months to 10 years). If the request is rejected, the foreigner is placed in a procedure to go back to the border. They can make an appeal against the decision and enter into a spiral that is very long with successive appeals possible (see Table 1).

For the entire duration of the examination of their case, the asylum seeker cannot move around on French soil. They are "conducted" to a Holding Zone. Previously, these were administratively undetermined spaces. Today, the Holding Zone is a clearly identified and defined space using regulatory roads. Nonetheless, their status stays unclear. The foreign person cannot move freely (and is restricted); yet the Holding Zone is not a prison as it is not managed by the penitentiary administration, and because the person is free to take a train or a plane without entering the terri-

Table 1. Successive procedures possible to obtain the right to asylum in France (valid in 2008).

\begin{tabular}{|c|c|}
\hline 1. & Submit a request at OFPRA \\
\hline 2. & OFPRA refuses \\
\hline 3. & $\begin{array}{c}\text { Appeal possible at National Court of Asylum } \\
\text { Seekers (Cour Nationale du Droit d'Asile, or } \\
\text { CNDA) }\end{array}$ \\
\hline 4. & CNDA refuses \\
\hline 5. & Appeal against CNDA decision \\
\hline 6. & $\begin{array}{c}\text { Appeal possible at State Council (Conseil d'Etat) } \\
\text { and/or the European Court of Human Rights }\end{array}$ \\
\hline 7. & Negative decision \\
\hline 8. & $\begin{array}{c}\text { Re-examination by OFPRA for new elements } \\
\text { (without any legal limit in terms of number of } \\
\text { appeals) }\end{array}$ \\
\hline
\end{tabular}


tory. Like the Holding Zones, Centres of Administrative Rentention, or CRAs, are not prisons as the foreigners can move freely in the spaces that are sometimes enclosed with barbed wire. These are places where the dismissed asylum seekers, people whose papers are being processed, or who are being taken back to the border are "retained". By not being precise from a juridical point of view, these zones seem to be extra-territorial and require exceptional procedures. They could be considered as sorts of enclaves in the centre of national territory, non-territories.

We begin to get a sense of the complexity of the border as it applies to the asylum seeker. When the border "fails" in its conventional sense, we have started to develop formal territorial and administrative "spaces" that keep the asylum seeker "out" until the matter is settled. In the potentially long process and during a number of appeals that the asylum seeker has a right to engage in, their territorial status is "suspended". They are physically present, but administrative ghosts. They are free, but cannot move. We can see them, but we do not have the right to host them. They exist in a territorial limbo.

An analysis of the concrete case of Strasbourg allows us to enrich our understanding of the border as it exists today. We shall see that the presence of strong local networks counters this sense of territorial suspension, of non-space.

\section{Strasbourg: a European city and a border city in the east of France}

A look at data from the OFPRA database (Refugees Forum 2006) shows us the relative popularity of Strasbourg as a destination city for asylum seekers. If we consider Alsace where Strasbourg is based, we see from Table 2 below that neither the Haut Rhin nor Bas Rhin regions that make up Alsace appears in the top 10 regions.

A look at the map (Figure 1) above of popular metropolitan locations for asylum seekers shows again the overwhelming popularity of the Paris region (to which we can attach the regions of Loiret and Oise). However, here we see Strasbourg in fourth place. How can one explain its attractiveness? Which asylum seekers does Strasbourg attract?
Table 2. Total number of asylum seekers from 1993 to 2006: the top 20 regions.

\begin{tabular}{|r|c|c|}
\hline Rank & Region & $\begin{array}{c}\text { Total number of ap- } \\
\text { plicants }\end{array}$ \\
\hline 1 & Ville de Paris & 127,352 \\
\hline 2 & Seine Saint Denis & 41,982 \\
\hline 3 & Rhône & 20,727 \\
\hline 4 & Val d'Oise & 20,352 \\
\hline 5 & Val de Marne & 14,885 \\
\hline 6 & Bouches du Rhône & 14,065 \\
\hline 7 & Hauts de Seine & 10,599 \\
\hline 8 & Essonne & 10,111 \\
\hline 9 & Seine et Marne & 9,919 \\
\hline 10 & DOM / TOM & 9,744 \\
\hline 11 & Yvelines & 8,707 \\
\hline 12 & Bas Rhin & 7,641 \\
\hline 13 & Nord & 7,236 \\
\hline 14 & Seine Maritime & 6,298 \\
\hline 15 & Haute Garonne & 6,264 \\
\hline 16 & Loiret & 5,904 \\
\hline 17 & Alpes Maritimes & 5,292 \\
\hline 18 & Loire Atlantique & 5,174 \\
\hline 19 & Haut Rhin & 4,651 \\
\hline 20 & Oise & 4,274 \\
\hline
\end{tabular}

Source: OFPRA, in Refugees Forum (2006).

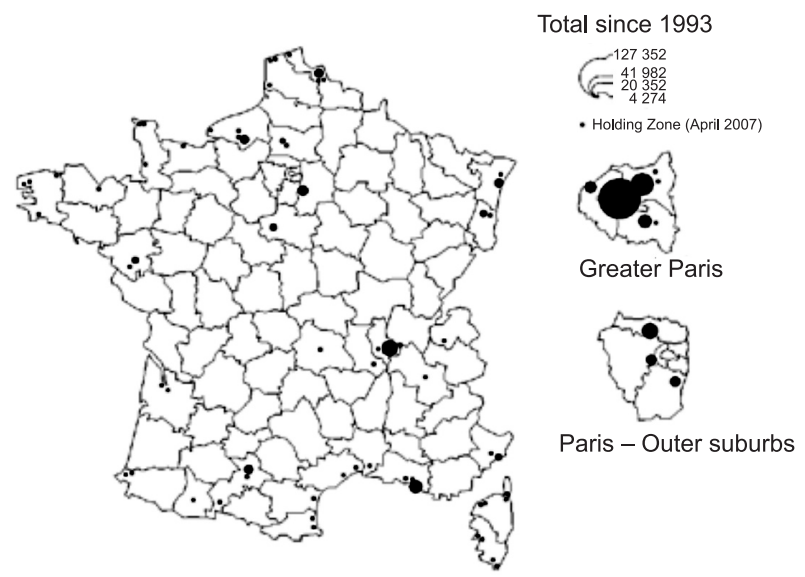

Figure 1. Number of files opened at the Prefecture from 1993 to 2006: the top 20 regions. Source: OFPRA - DGDDI / Anafe.

\subsection{Strasbourg: a European city in the east of France}

In 2004, almost 850 files coming from Strasbourg were opened at OFPRA. The OFPRA data were completed with information from the Association for Asylum Seekers in Strasbourg (Collectif d'Accueil pour les Solliciteurs d'Asile à Strasbourg, or CASAS) in order to determine the 
Table 3. Top 10 nationalities of asylum seekers in France and Strasbourg in 2004

\begin{tabular}{|c|c|c|c|c|c|}
\hline \multirow[b]{2}{*}{ Rank } & \multicolumn{2}{|c|}{ France: asylum seeker files (OFPRA) } & \multicolumn{3}{|c|}{ Strasbourg: people seen by CASAS } \\
\hline & Country of origin & $\begin{array}{l}\text { Number } \\
\text { of files }\end{array}$ & Country of origin & $\begin{array}{l}\text { People } \\
\text { seen by } \\
\text { CASAS }\end{array}$ & $\begin{array}{c}\text { Number } \\
\text { of OFPRA } \\
\text { files } \\
\text { opened }\end{array}$ \\
\hline 1 & Turkey & 4,409 & Russia & 134 & 116 \\
\hline 2 & China & 4,188 & Armenia & 120 & 60 \\
\hline 3 & Algeria & 3,702 & Georgia & 79 & 50 \\
\hline 4 & DR Congo & 3,353 & Congo- Brazzaville & 47 & 19 \\
\hline 5 & Haiti & 3,067 & Turkey & 47 & 27 \\
\hline 6 & $\begin{array}{c}\text { Former republics of Yugoslavia } \\
\text { (excluding Bosnia-Herzegovina } \\
\text { and Serbia-Kosovo) }\end{array}$ & 2,378 & Cameroon & 40 & 23 \\
\hline 7 & Russia & 2,165 & RD Congo & 36 & 32 \\
\hline 8 & Sri Lanka & 2,090 & Azerbaijan & 34 & 25 \\
\hline 9 & Moldavia & 2,058 & Angola & 32 & 10 \\
\hline 10 & Bosnia-Herzegovina & 2,012 & Serbia-Kosovo & 28 & 12 \\
\hline
\end{tabular}

Source: OFPRA and CASAS.

origin of the applicants. The statistics provided by CASAS do not exactly match the number of asylum-seeker files opened at OFPRA that originated from Strasbourg. Nonetheless, the figures are close: 965 people registered by CASAS versus 843 files opened at OFPRA (Table 3 ). In addition, the interviews with asylum seekers conducted by the organisation allow us to understand their presence in the city.

A comparison of the top ten nationalities of asylum seekers in Strasbourg versus the whole of France gives us some insight. Six nationalities of asylum seekers are those from the eastern edges of the EU. The geographic location of Strasbourg makes it a step, or a rallying point, along one of the routes of migrants that come from Eastern Europe.

\subsection{Links to local communities and the Prefecture}

So where exactly do the asylum seekers come from? Russia is at the top of the table. The Prefecture at Strasbourg, and this is no secret, has regularly shown itself to be receptive to the drama in Chechnya. The work of associations and the community, which never ceases to grow, helps the new arrivals. Networks of human smugglers are aware of this and target the destination. An opposite case: Moldavia, in 9th place in the table of asylum seekers in France, and almost nonexistent in
Strasbourg. The geographic location of this country should bring asylum seekers to Strasbourg, yet CASAS saw only six people in 2004, four in 2005 and four in 2006. In this case, the reception at the Prefecture is not particularly welcoming, the community is nonexistent, and the networks of smugglers have their points of reference in other places. China, Haiti and Sri Lanka are also not very present in Strasbourg as their nationals come to France by air, and so principally to Paris. Nevertheless, Strasbourg records all the major nationalities that are present in France (Congolese, Angolan) which have their own community links (in particular the Congolese and Armenians).

\subsection{Home of the European Court of Human Rights}

For some, this positive French image embodied by Strasbourg is further enhanced by the presence of the Court of Human Rights, as though the presence of this Court could not but reinforce the principles that are already established and alive in Strasbourg society.

The interviews with asylum seekers conducted in 2007 by CASAS confirm that for many people France still has an image of the "Country of Human Rights" and so will protect them. Thus we see asylum seekers who want absolutely to come to France and stop in Strasbourg. Others, for financial reasons, are abandoned in Stras- 
bourg by smugglers whereas their journey was intended for Paris. As a consequence, Strasbourg is a real eastern gateway to France.

\subsection{Empathetic and active associations for historical reasons}

Traditionally, Strasbourg has not been a city of immigration but rather one of emigration. The last three Franco-German wars had the effect of delocalising populations, sometimes in a very permanent manner: emigration after 1871, the expulsion of Germans, even those born on French soil, following the Treaty of Versailles. The 1939 exodus to the south of France (approximately 380,000 Strasbourgeois and inhabitants of the border regions of Saint-Louis and Lauterberg) put many people from Alsace in the position of being in exile. The administrative, religious and political structures that were unique to Alsace, well organised and very active, were temporarily reconstructed (the provisional Municipality of Strasbourg in Perigeux, for example). It is therefore no coincidence that one of the largest associations today for the defence of migrants in France was created by Protestants from Alsace in 1939: the CIMADE. Today, Strasbourg proposes a network of associations that are very active in this area: the Education Without Borders Network (RESF, or Réseau Education Sans Frontière), the Association for Asylum Seekers in Strasbourg (CASAS, or Collectifd'Accueil pour les Solliciteurs d'Asile à Strasbourg), the Orientation Centre for Asylum Seekers (CODA, or the Centre d'orientation pour les demandeurs d'asile), and THEMIS, an association set up to uphold children's rights and which takes care of children that have been separated from their asylum-seeking parents.

Strasbourg is therefore identified as both a city belonging to France and a EU border locality. What set it apart, above all, are the specific characteristics of the local society: well-established communities, associations, and their actions.

Given the presence of a great number of asylum seekers in Strasbourg, we can look at a further evolution of the border, with examples of how it applies in Strasbourg. We can use it to test the hypothesis that a new type of border is created in the heart of our daily territories: one that keeps out the asylum seeker. This border separates our well-organised and well-adapted territories (for European Union citizens and guests) from the every day "non-territories" of asylum seekers marked by instability and uncertainty.

\section{A new border: controlling the time and everyday space of the asylum seeker}

So far, we have considered the creation of a territorial limbo, a "non-space" in which the asylum seeker finds himself or herself, and how links with local associations and community infrastructure counter the sensation of administrative "weightlessness" during the application process. This explains the remarkable popularity of Strasbourg as a destination for refugees.

Here we look at a more conceptual, but nonetheless very real border created through the management of the everyday spaces that the asylum seeker finds himself in. We see that our relationship, familiarity and control of time in our everyday spaces are essential to establishing a sense of ownership and belonging. What better way to continue keeping the asylum seeker "out" than to disrupt the possible relationship he can establish with his everyday spaces, particularly through the manipulation of his time? To explore this idea, we use the concept of everyday territory or space based on the theories of Di Méo (1996) and Lefebvre (1974).

The first idea brings up the concepts of ownership and belonging (Di Méo). A place is owned when it is familiar and we can control or manage it: the codes and points of reference allow us to evolve within it in safely and, importantly, without too much risk of being excluded. The main codes are integrated or built-in; very often we are not even conscious of them.

Belonging to a territory is linked to the position that one has in a group. One's role and position determine the nature of one's relationships with others, and their recognition. Territory is defined as a "spatial self which demarcates each group with a geographical base" (Di Méo 1996); a network of social spatial relations that corresponds to the needs of a human being: to nourish oneself physically, mentally, emotionally; to sleep; to 
preserve and protect one's body (care, hygiene, clothing). Temporal rhythms, symbolic reference points and familiar spaces organise the territory and reinforce the sense of ownership.

Lefebvre (1974) suggests another concept: that of everyday territory or space. He sees space as a social product that in turn shapes society. It is a triplicity which forms a whole composed of 1) representations of space: the conceptual space of urban planners, with its own codes and signs and symbols that have been intellectually drawn up to organise our interactions; 2 ) spatial practice: this refers to spatial relationships between objects and products, and therefore to our use of everyday space, which has a certain coherence and which allows us to guarantee a certain competence and performance as members of society that use the space; and 3) representation spaces: these are spaces which are the lived experiences that come about as a result of interactions between representations of space and spatial practices.

Unavoidably, the asylum seeker creates links with his everyday territory at the heart of which he goes about his business, which can take several months, considering the time of examination of his file by OFPRA and the different appeals that may take place. He will begin to own the space which he needs to master, with the help of the associations or his friends. He starts to knit social relationships that become part of his anchorage. His daily activities oblige him to become familiar with the new codes and signs which can start to organise his new environment, little by little, to the consternation of certain people. He has a means to start to move out of his territorial limbo.

\subsection{Control of time as a border}

The structuration theory of Giddens (1984, French transl. 2005) takes the idea further by cutting across three dimensions that are at the heart of the matter: daily life, space, and time. Specifically, Giddens proposes that physical co-presence in space is no longer imperative for a social activity. One could be present virtually, at a distance. The binding factor in the creation of social activities is therefore time. We see this idea elaborated below:
- Space and time are separate in modern society: social activity is no longer attached to the simultaneous presence in a place. Today, it is characterised by the extraction of social relations from their usual contexts and their recreation in a new type of time-space (Giddens uses the expression "spatial-temporal fields", 2006: 30).

- So from now on spaces are fed by a quantity of relations at a distance, without co-presence, the structuration of these new space-times are not possible except in time, the foundation of the control of space (Giddens 2006: 27).

For the asylum seeker, this final, personal and everyday border is not the classical barrier or filter as he is within the territory. Here the border is a lack of control or inability to manage his own time, which in turn renders it impossible for him to create a relationship with space that is personal and social. This border is imposed in the following ways.

\subsection{Uncertainty around time: the deadline}

The coordination of time of the asylum-seeking process uses an extremely useful tool: the deadline. It organises the time of the asylum seeker in an extremely restrictive manner because missing out on a deadline is the equivalent of being excluded from the system. It imposes travel (expensive from Strasbourg) on fixed dates; responses or procedures that have to be made in fixed periods of time; organised waiting (spending an entire night at the Prefecture is a common occurrence in Strasbourg and in other cities). "Theoretical deadlines are the weapon for fighting against liberties while pretending to be a democrat" (Eolas, Diary of a Lawyer). We can illustrate this with an example: asylum seekers, in keeping with European rights, can make an appeal at the National Court of Asylum (Cour Nationale de la Demande $d^{\prime}$ Asile, CNDA). The conditions for filing an appeal at the CNDA have become more demanding as of autumn 2007. Now the asylum seeker has a deadline of 15 days (compared with 30 days previously) after the decision of OFPRA, which comes to him via a registered letter. The deadline starts from the first attempt to deliver the letter. The letter is only sent by post and the 15 days 
include the delivery time. Any file that misses the deadline is not examined. In effect, this shortens the time available to file an appeal. In the same way, the so called "priority" procedures have not stopped multiplying. According to the French Interior Minister at the European Court of Human Rights, $89 \%$ of the requests in the Holding Zone were examined in less than 4 days. The time of the asylum seeker is thus extremely restricted by precise milestones, which are as much as threats of exclusion from the system. These milestones will determine his space and indirectly control him. Without any help from others (friends, parents, associations, lawyers, and so on) it is almost impossible for an asylum seeker to complete the process. Here we understand the importance of the host centre and the links that he makes everyday.

\subsection{Uncertainty around space: housing}

The coordination of the space of an asylum seeker is equally marked by similar milestones that determine his time; his space is characterised this time by great instability. One extremely revealing example is housing. Even though admittedly the number of places at the Welcome Centre (CADA) has increased, there is never enough housing. The assignment to a CADA place is not regionalised: a request is subject to the whim of places that are free, no matter where they are. An asylum seeker who has opened a file in Strasbourg may find himself overnight at the other end of France, abruptly cut off from any social links that he may have managed to establish. If access to CADA is not possible, he is put up in a hotel with the obligation to move every 15 days (this is the norm in Strasbourg), or in emergency shelters. So instability is terms of housing is the rule. The sense of instability is reinforced by police surveillance in the places frequented by asylum seekers. The premises of associations regularly have Air and Border Police on duty in the vicinity. Even if the asylum seeker is not in an irregular situation, he lives in fear of being checked, with unpredictable consequences. He has to change his routine, and sometimes avoid going to those precious places where he has succeeded in creating his first social contacts. The coordination of the daily time of an asylum seeker is thus characterised by strong instability, which seems rather to be an "un-coordination" of time.

The associations which come to the assistance of asylum seekers unwittingly participate in this "un-coordination". They manage to respond in an emergency using their reactivity and flexibility: mobilising militants and volunteers, with a capability of using the information networks of different institutions. In December 2007, for example, in the light of an unexpected influx of Chechen refugees, the associations in Strasbourg collected emergency funds and organised housing at a hotel for families that would have otherwise been left in the street. By providing a solution when the system fails (which in turn could potentially bring the dramatic nature of the system to the attention of the public and media), the associations involuntarily contribute to re-enforcing the border created through the "un-coordination" of the daily time of the asylum seeker.

\section{Conclusion}

Asylum seeking raises questions for the geographer and his or her conceptions of space and border. A first conclusion is obvious: if we had any doubts, the State's control over its borders does not disappear. The French state, like others, uses European arrangements to its own advantage, with limits, however. French citizens have a sense of expansion: easy mobility and disappearing borders. However, the path of an asylum seeker in France demonstrates how different this scenario could be. For the asylum seeker, the European border system extends its barriers and its specific spaces outside the Union in order to prevent him from leaving his own country. The system develops other barriers and other spaces on the inside of the Union (such as the Holding Zone, this non-territory) to keep the asylum seeker "out".

Strasbourg is an excellent location to examine this dichotomy. A capital city at the heart of the European Union, it attracts an unusually high number of asylum seekers primarily as it is a French city, with France being seen as the "home of human rights". We find that the city offers a special social network imbued with its rich 
history, and a migrant culture. It brings together the associations, communities and Prefectural authorities that are open to dialogue with certain nationalities. Information circulates among smugglers and asylum seekers, who use this location in a preferential way. Communities can be reinforced and attract more people, reinforcing the image of asylum seekers as "burden" people who believe in "chosen immigration", or "immigration choisi".

However, as soon as the asylum seeker succeeds in arriving on our territory in spite of all the obstacles, what do we do with him? He has managed to produce a coherent story that protects him from being sent back to the border: here "among us", in the heart of our everyday territories with which he will start to create links. We create a new border for him during the time that his asylum seeker's case is being considered, a time that can be prolonged in a significant manner if it involves appeals. The asylum seeker is "enclosed" in a daily space that is extremely constrained by administrative rules, which, if they are not respected, will expel him.

But what if the great poverty that we are keeping out with our borders was not economic? Do not our territories deprive themselves of an immense richness, that of hospitality? According to Derrida (1997), hospitality should have no limits, it should be essentially private, and should inspire the laws that govern us.

"At first you float like in a weightless state. You have become a foreign body, a peddler of yourself. A vagabond of space and time. You are a wanderer, a shadow without a shadow, without documents, without a face and without age... But sooner or later, you will throw down your anchor. House your shadow, set down your suitcases. You cling to every day. Face the looks of other while occupying their territory. Tame their tolerance. Learn to become formless. Take from time to time the colour of the wall to allow yourself to forget".

Source: Beloved country of my childhood, Words of the uprooted, Gueno (2005)

\section{References}

\section{Works and articles}

Clochard O., Decourcelle A. \& Intrand C., 2003. Zones $\mathrm{d}^{\prime}$ attente et demande $\mathrm{d}$ 'asile à la frontière : le renforcement des contrôles migratoires? (Holding zones and asylum requests at the border: the reinforcement of migration control?). Revue Européenne des Migrations Internationales.

Derrida J. \& Dufourmantelle A., 1997. De l'hospitalité (Of hospitality). Calmann-Lévy.

Di MÉo G.,1996. Les territoires du quotidian (Territories of the everyday). L'Harmattan.

GIDDENS A., 2005. La constitution de la société (The constitution of society). PUF, (published in English in 1984).

Giddens A., 2006. Les conséquences de la modernité (The consequences of modernity). L'Harmattan (published in English in 1990).

GISTI 2008, Le guide de l'entrée et du séjour des étrangers en France (The guide to entry and stay of foreigners in France) La Découverte.

GuENO J.P., 2005. Cher pays de mon enfance, parole de déracinés (Beloved country of my childhood, words of the uprooted). Les Arènes Editeurs.

Julien-Laferriere F., Labayle H. \& Edstrom O., 2005. La politique européenne d'immigration et d'asile: bilan critique cinq ans après le traité d'Amsterdam (European Policy on immigration and asylum: a critical assessment five years after the Treaty of Amsterdam). Bruxelles, Bruylant.

Le Pors A., 2008. Le droit d'asile (The right to asylum). PUF.

Lefebvre H., 1974. La production de l'espace (The production of space). Economica.

NoIriel G., 2006. Réfugiés et sans papiers, La république face au droit d'asile XIXè-XXème siècle (Refugees and people without documents. The Republic in terms of the right to seek asylum $19^{\text {th }}-20^{\text {th }}$ century). Pluriel.

TAN S., 2006. La où vont nos pères (The arrival). Dargaud.

\section{European Directives}

Council Directive 2004/83/EC of 29 April 2004 on minimum standards for the qualification and status of third country nationals or stateless persons as refugees or as persons who otherwise need international protection and the content of the protection granted (adopted 10 October 2006).

Directive concernant les normes minimales relatives aux conditions pour pouvoir prétendre au statut de réfugié ou à une autre protection (entrée en vigueur le 10 octobre 2006).

Council Regulation (EC) No 343/2003 of 18 February 2003 establishing the criteria and mechanisms for determining the Member State responsible for examining an asylum application lodged in one of the Member States by a third-country national).

Règlement (CE) no 343/2003 du Conseil du 18 février 2003 établissant les critères et mécanismes de détermination de l'État membre responsable de l'examen d'une demande d'asile présentée dans l'un des États membres par un ressortissant d'un pays tiers. 


\section{Statistics: Sources and reports}

CIMADE Report 2006 (CRA Geispolsheim): http://www. cimade.org/assets/0000/0124/rapport2006strasbourg. pdf

Eolas: http:/ / www.maitre-eolas.fr.

Forum Refugies, 2006. L'asile en France et en Europe, Etat des lieux 2006 (Asylum in France and Europe: status 2006), $187 \mathrm{p}$.

GOUTEYRON A., 2006. Le contrôle relatifà l'Office de protection des réfugiés et des apatrides (OFPRA), Rapport d'information fait au nom de la Commission des Finances, du contrôle budgétaire et des comptes économiques de la Nation (Audit of the Office of Protetion of the Refugees and Stateless. Information report commissioned by the Commission of Finance, Budget Control and Economic Accounts) (1), Senat, session ordinaire 2005-2006.
MARIANI T., 2003. La politique européenne d'asile, Rapport d'information (European policy on asylum, Information report) N817, Assemblée Nationale, 147p.

Migrations Internationales (International migrations) 19 (2): 157-189. Available online at l'URL : http:/ / remi.revues. org/document2948.html

OFPRA statistics sources: http://www.comede.org/rubrique.php3?id_rubrique=33, page accessible on 3 September 2007.

Prefecture de la Région Alsace. 2005. Programme Régional d'intégration des populations immigrées (Regional programme of the integration of immigrant populations), 97p.

United Nations High Commissioner for Refugees UNHCR, 2001. Asylum Applications in Industrialised Countries: 1980 1999, 201p. 